\title{
Distribution of Camphor Monooxygenase Genes in Soil Bacteria
}

\author{
Ngadiman $^{1)}$, Hikaru Suenaga ${ }^{2)}$, Masatoshi Goto ${ }^{3)}$ and Kensuke Furukawa ${ }^{3)}$
}

1. Laboratory of Microbiology, Faculty of Agriculture, Gadjah Mada University, Yogyakarta, Indonesia.

2. National Institute of Advanced Industrial Science and Technology, Tokyo, Japan.

3. Laboratory of Applied Microbiology, Faculty of Agriculture, Kyushu University, Fukuoka, Japan.

\begin{abstract}
In microbial degradation of camphor, the first step is oxidation by multiunit enzyme, camphor monooxygenase, encoded by cam genes $(\operatorname{cam} A, B, C)$. Seven camphor-utilizing bacterial strains have been isolated from soil at various locations. CamA,B,C genes of Pseudomonas putida strain PpG1 and strain GF2001 were used as probes to explore their abundance in the camphor-utilizing bacteria. Southern analysis revealed that all of the cam genes of GF2001 could hybridize well to the SpeI-digested genomic DNA of strains tested, whereas PpG1 cam genes were not. This result suggested that the GF2001 type cam genes are widely distributed among the camphorutilizing strains in the environment. Thus strain GF2001 and seven newly isolated strains share a common evolutionary origin.
\end{abstract}

Key words: Camphor monooxygenase genes, gene distribution, sail bacteria.

\section{Introduction}

Camphor that belongs to toxic compound could be degraded by soil bacteria. The first well characterized camphor degrader is Pseudomonas putida PpG1 that harbors a CAM plasmid (Bradshaw et al., 1959). The plasmid contains cam genes expressing a multiunit enzyme, camphor monooxygenase (CamMox). CamMox catalyzes the initial reaction of camphor degradation by inserting one oxygen atom into substrate. Structurally and biochemically, CamMox consists of cytochrome P450 (P450cam), putidaredoxin, and putidaredoxin reductase that is encoded by cam $C, B, A$, respectively (Katagiri et al., 1968; Gunsalus and Sligar, 1978; Koga et al., 1986). Recently, Ngadiman et al. (2004) reported a new bacterial strain, Pseudomonas putida GF2001, that also has high ability to

*Corresponding author: Ngadiman, Department of Agriculture Microbiology, Faculty of Agriculture, Gadjah Mada University, Bulaksumur, Yogyakarta 55281, Indonesia. Tel. +62-274-523065, Fax. +62-274523062. E-mail: ngadiman@faperta.ugm.ac.id degrade camphor. Compared to PpG1, CamMox genes of GF2001 reside in the chromosome, different gene organization, and share about $61 \%$ homology on their nucleotide sequence.

It is well known that diversity of a gene family can be generated through a variety of genetic mechanisms both in the nature or laboratory (Danielson, 2002). Transfer and mutation of DNA have been taking place naturally at high rate. A variety of studies documented horizontal gene transfer occurred in natural environment via transformation, conjugation or transduction. In the meanwhile DNA mutation proceeds by availability of many mutagenic agents in the nature. These processes encourage the potential events of natural genetic engineering in the environment (Bushman, 2002). Furukawa et al. (1993) summarized that the diversity of some structural genes occur through various genetic events. Some are promoted by gene transfer among bacteria since the catabolic genes often reside in the large transmissible plasmid. Some other was 
through genetic duplication. Once duplicated, the extra copy of the gene diverges much faster by the accumulation of mutations. Evolutionary divergence of related genes can be traced by comparison of their nucleotide sequence, and each class of genes shows its own characteristic rate of evolution. Therefore, each class or family has various levels of similarity (Dus, 1984).

Concerning with the presence of camphor monooxygenase genes existed in Pseudomonas putida GF2001 and PpG1, this paper describes how such genes are distributed among the camphor degraders in the environment.

\section{Materials and Methods Materials}

The following basal salt medium (BSM) was used to enrich and isolate camphor degrading bacteria. BSM containing (in grams per liter): $\mathrm{K}_{2} \mathrm{HPO}_{4^{\prime}}$ 4.3; $\mathrm{KH}_{2} \mathrm{PO}_{4^{\prime}}$ 3.4; $\left(\mathrm{NH}_{4}\right)_{2} \mathrm{SO}_{4}, 2.0 ; \mathrm{MgCl}_{2}, 0.16 ; \mathrm{MnCl}_{2} .4 \mathrm{H}_{2} \mathrm{O}$, $0.001 ; \mathrm{FeSO}_{4} .7 \mathrm{H}_{2} \mathrm{O}, 0.0006 ; \mathrm{CaCl}_{2} .2 \mathrm{H}_{2} \mathrm{O}$, 0.026; and $\mathrm{Na}_{2} \mathrm{MoO}_{4} .2 \mathrm{H}_{2} \mathrm{O}, 0.002$ (Furukawa and Miyazaki, 1986). Genomic DNAs of strain PpG1 and GF2001 was prepared by standard method (Ausubel et al., 1998). Oligonucleotides (Table 1) for amplifying cam $C, A, B$ genes were synthesized by HSS company (Hokaido, Japan). DIG-dUTP labeling kit was purchased from Roche corporation (Germany). Southern blot membrane was Biodyne ${ }^{\mathrm{R}} \mathrm{B} 0.45 \mu$ from Pall corporation (Pensacola, USA).

\section{Isolation of camphor degrading bacteria}

Several soils as isolate sources were taken from different site of origin (Table 2). One gram of each soil was poured in BSM liquid medium supplemented with camphor $(5 \mathrm{~g} / \mathrm{l})$ and incubated on rotary shaker (100 $\mathrm{rpm})$ at $30^{\circ} \mathrm{C}$ for 1 month as enrichment culture. The culture showing microbial growth was subjected for isolation. Each culture was plated on BSM agar containing camphor as the sole carbon source. Camphor was provided as vapor by placing crystals on the lid of a petridish. Incubation was in $30^{\circ} \mathrm{C}$ room for 2 weeks and the growth of bacteria was observed in interval time. Colonies that show an abundance growth response were purified and selected for next experiment.

Table 1. Primers for amplifying cam genes

\begin{tabular}{|c|c|c|}
\hline \multirow{2}{*}{$\frac{\text { NoPrimer (F: forward; R: reverse) }}{1 \text { F: 5'-TTAGCCAACCCGCGTTCC-3' }}$} & \multicolumn{2}{|c|}{$\operatorname{Tm}\left({ }^{\circ} \mathrm{C}\right)$ Targeted gene } \\
\hline & 58.1 & CamC-PpG1 \\
\hline R: 5'-AGCACGCACTCCCATGTG-3' & 58.1 & (1248 bp) \\
\hline 2. F: 5'-CACATGGGAGTGCGTGC-3‘ & 56 & CamA-PpG1 \\
\hline R: 5'-CGCTATGGGGCAAAACGG-3’ & 58.1 & (1268 bp) \\
\hline 3 F: 5'-CCGTTTTGCCCCATAGCG-3' & 58.1 & CamB-PpG1 \\
\hline R: 5'-GGCTCGCAGTGGTTTACC-3' & 58.1 & (323 bp) \\
\hline 4. F: 5'-CCTGAATGTAGCCGCAC-3' & 54 & CamC-GF2001 \\
\hline R: 5'-CAGGGCAGTCATGACTG-3' & 54 & (1215 bp) \\
\hline 5. F: $5^{\prime}$-CATATGGAAATCAATAGCCCAGAGC-3' & 58 & CamA-GF2001 \\
\hline R: 5'-AAGCTTCGGTTGGGTTGGTGTGAG-3' & 62.2 & $(1286)$ \\
\hline 6 F: 5'-CATATGCCCAAAGCCACGTTTGTTC-3" & 60.5 & CamB-GF2001 \\
\hline R: 5'-AAGCTTCCACTGGCTTTCGGCAAC-3' & 62.2 & (324) \\
\hline
\end{tabular}

\section{PCR amplification and labeling of cam genes.}

camC, A, B genes of PpG1 and GF2001 were amplified by PCR using primer as noted in Table 1. PCR mixture (in $50 \mu \mathrm{l}$ ) containing $1 \mu \mathrm{g}$ genomic DNA as a template, 1x Taq DNA polymerase buffer (Promega), $0.2 \mathrm{mM}$ (each) dNTPs, $2 \mathrm{mM}$ $\mathrm{MgCl}_{2}, 10$ pmol of each primer, $0.5 \mathrm{U}$ Taq DNA polymerase. Amplification of the DNA was done for 30 cycles under the following conditions: denaturation, $94^{\circ} \mathrm{C}(1$ $\mathrm{min})$; primer annealing, $\mathrm{Tm}-5^{\circ} \mathrm{C}(1 \mathrm{~min})$, and primer extension, $72^{\circ} \mathrm{C}(1.5 \mathrm{~min})$; plus one additional cycle with a final $10 \mathrm{~min}$ chain elongation. The amplified DNA 
fragments of each gene were used as a template DNA for labeling with DIG-dUTP according to the suppliers' protocol (Roche).

\section{Pulse Field Gel Electrophoresis (PFGE).}

The intact cells of camphor degraders were embedded into agarose gel suitable for DNA separation by PFGE in accordance with protocol from the manufacturer (BioRad laboratories AG, Switzerland). This gel block was then digested by SpeI endonuclease, and DNA fragments were separated by clamped homogenous electric electrophoresis (CHEF) for $24 \mathrm{~h}$ using the CHEF-DRII system (Bio-Rad). Electrophoresis was done in $45 \mathrm{mM}$ TriBorate and $1 \mathrm{mM}$ EDTA $(\mathrm{pH} \mathrm{8.3)}$ at $6 \mathrm{~V} /$ $\mathrm{cm}$ and $10^{\circ} \mathrm{C}$ (Ausubel et al., 1998).

\section{Southern analysis}

DNA fragments separated by PFGE were transformed onto Biodyne ${ }^{\mathrm{R}} \mathrm{B} 0.45 \mu$ membrane using the capillary flow method (Ausubel et al., 1998). The DNA was fixed to the membrane by a UV crosslinker (BioRad) according to manufacturer's protocol. The blot was hybridized to the DIG-dUTP labeled cam genes under normal stringency (hybridization solution contains $50 \%$ formamide and washing step is performed at $\left.68^{\circ} \mathrm{C}\right)$.

\section{Results}

\section{Growth response of isolated strains.}

A number of bacterial strains were isolated from camphor enriched culture. To isolate and confirm their ability to utilize camphor, each strain was streaked on agar BSM supplemented with camphor as sole carbon source. Upon comparison with the established camphor degrader, P. putida strain PpG1, eight newly isolates relatively showed a less abundance or fairly growth response (Table 2).
Table 2. Growth response of some selected strains in basal salt medium (BSM) agar supplemented with camphor as sole carbon source

\begin{tabular}{|c|c|c|c|c|}
\hline \multirow{2}{*}{$\begin{array}{l}\text { Strain } \\
\text { incubation }^{2)}\end{array}$} & \multirow{2}{*}{$\begin{array}{l}\text { Source of } \\
\text { origin }^{1)}\end{array}$} & \multicolumn{3}{|c|}{ Growth response after } \\
\hline & & 2 days & 7 days & 14 days \\
\hline $\mathrm{PpG}_{1}^{3)}$ & America & ++ & +++ & ++++ \\
\hline GF2001 & $\begin{array}{l}\text { Hakozaki, } \\
\text { Fukuoka, } \\
\text { Japan }\end{array}$ & + & ++ & +++ \\
\hline N-32 & $\begin{array}{l}\text { Kashii, } \\
\text { Fukuoka, } \\
\text { Japan }\end{array}$ & + & ++ & +++ \\
\hline $\mathrm{N}-44$ & $\begin{array}{l}\text { Hakozaki, } \\
\text { Fukuoka, } \\
\text { Japan }\end{array}$ & + & ++ & +++ \\
\hline $\mathrm{N}-47$ & $\begin{array}{l}\text { Okinawa, } \\
\text { Japan }\end{array}$ & + & ++ & +++ \\
\hline N-51 & Africa & + & ++ & +++ \\
\hline N-53 & Africa & - & ++ & +++ \\
\hline N-55 & $\begin{array}{l}\text { Kaizuka, } \\
\text { Fukuoka, } \\
\text { Japan }\end{array}$ & - & ++ & +++ \\
\hline N-60 & $\begin{array}{l}\text { Kaizuka, } \\
\text { Fukuoka, } \\
\text { Japan }\end{array}$ & + & ++ & +++ \\
\hline
\end{tabular}

Note:

1). Some are the same city, but different site

2 ). $-=$ no growth; $+=$ poor; $++=$ fairly; $+++=$ good; $++++=$ abundance

3). Strain PpG1 is an established camphor degrader (as reference).

All strain did not grow in BSM agar without camphor

Hybridization of cam genes with genomic DNA of selected isolates.

The results of southern analysis between $\operatorname{cam} C, B, A$ genes as probes and SpeI-digested genomic DNA of nine camphor degraders are presented in the Figure 1-3. The positive signals were clearly appeared by the hybridization analysis using cam $C, B, A$ genes from strain GF2001 as probes. In contrast, there was no hybridization signals appeared when PpG1 cam genes were used as probes. Relative comparison of the hybridized bands particularly in strain GF2001, N32, and N44 exhibited the similar position of the hybridized bands in all three probes (cam $C, A, B)$ used. 


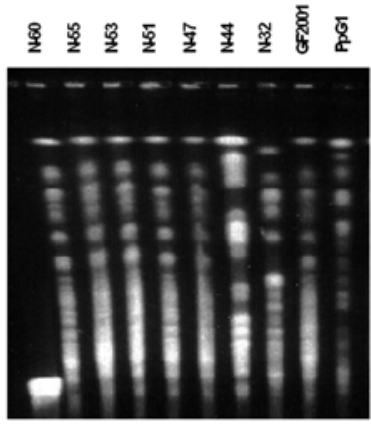

(a)

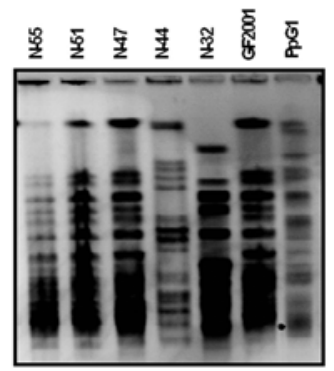

(a)

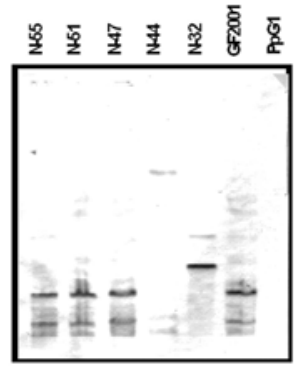

(b)

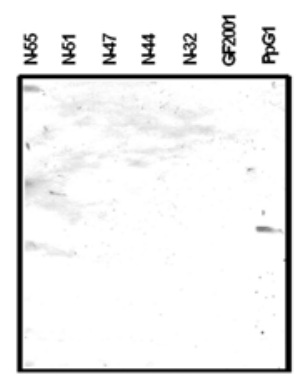

(c)

Figure 2. Distribution of camA gene in camphor degrading bacteria.

(a). PFGE analysis of SpeI-digested genomic DNA, (b). Southern analysis between the digested DNA and camAGF2001 as probe, (c). Southern analysis between the digested DNA and camA-PpG1 as probe

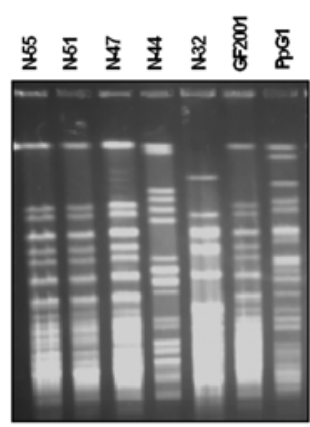

(a)

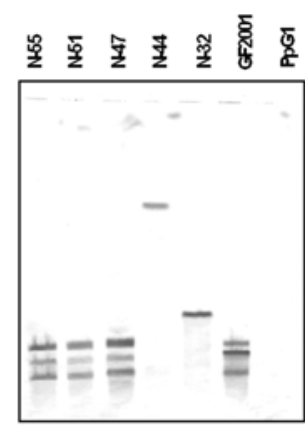

(b)

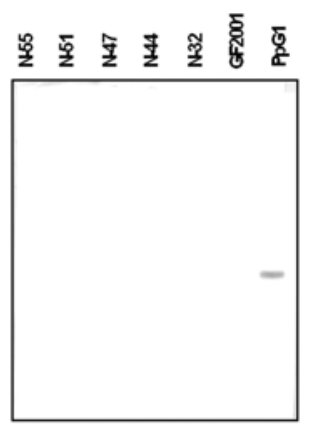

(c)

\section{Discussion}

Newly isolated strains exhibited the similar growth response on 'camphor' medium (Table 1), but different profile in their genetic structure was obtained (data not shown). By considering the origins of the soil sample, the results suggested that the microbial characteristics may has no much relation with the distance of strain
Figure 1. Distribution of cam $\mathrm{C}$ gene in camphor degrading bacteria.

(a). PFGE analysis of SpeI-digested genomic DNA, (b). Southern analysis between the digested DNA and camCGF2001 as probe, (c). Southern analysis between the digested DNA and camC-PpG1 as probe

Figure 3. Distribution of $c a m B$ gene in camphor degrading bacteria.

(a). PFGE analysis of SpeI-digested genomic DNA, (b). Southern analysis between the digested DNA and camBGF2001 as probe, (c). Southern analysis between the digested DNA and camB-PpG1 as probe 
phenotype on camphor medium but different genetic structure in the three selected strains also inquires a separated elucidation.

Positive hybridization with CamMox genes of GF2001 toward other camphor degraders exhibit high homology of nucleotide sequence among them, suggesting that they have a very close evolutionary relationship or share a common ancestry. While CamMox genes of PpG1 that has low homology reflecting distinct genes which may diverge at an early stage of evolution. The unique metabolic versatility of catabolic genes such as PpG1 CamMox genes often reveals greatly rearrangement of the genes (Furukawa et al., 1996). Since the cam genes of PpG1 resides in the transmissible plasmid (Chakrabarty, 1976), their transfer frequency is high. Once transferred, the genes seem to be greatly rearranged in the new host strain (Furukawa et al., 1993). By conjugation plasmid-borne genes are transferred at higher frequency than are chromosomal, and are transferred in homologous crosses more frequently than between heterologous species. The positive hybridization signal with cam genes of strain GF2001 against other camphor degraders that had been isolated all around the world allow to conclude that GF2001-type cam genes are more widely distributed among camphor-utilizing bacteria in the environment.

The similarity of signal position appeared in hybridization with probe $\operatorname{camC}$, $A, B$ could be a noticeable that the location of camC, A, B are in the SpeI fragment. In the previous identification, it was clearly demonstrated that camDC reside separately from camAB in Pseudomonas putida GF2001 (Ngadiman et al., 2004). These data suggested that their location is not so far although different cluster.

\section{Acknowledgement}

This research was partly supported by Overseas Economic Cooperation Fund Universitas Gadjah Mada (OECF-UGM) project through PIU-UGM (Project Implementation unit - Universitas Gadjah Mada), Yogyakarta, Indonesia.

\section{References}

Ausubel, F.M., Brent, R., Moore, D.D., Seidman, J.G., Smith, J.A., Strobel, K., Albright, L.M., Coen,D.M., and Varki,A., 1998. Current protocols in molecular biology. USA: JohnWiley \& Sons, Inc.

Bradshaw, W.H., Congrad, H.E., Corey, H.E., Gunsalus, I.C., Lednicer,D., 1959. Microbiological degradation of (+)-camphor. J. Am. Chem. Soc., 81, 5507

Bushman F., 2002. Lateral DNA transfer: Mechanisms and consequences. New York: Cold Spring Harbor Lab. Press.

Chakrabarty, A.M., 1976. Plasmids in Pseudomonas. Ann. Rev. Genetic, 10, 710.

Danielson, P.B., 2002. The cytochrome P450 superfamily: Biochemistry, evolution, and drug metabolisms in human. Curr. Drug Metabolism, 3, 561597.

Dus, K.M., 1984. Camphor hydroxylase of Pseudomonas putida: Vestigates of sequence homology in cytochrome P450cam, putidaredoxin, and related proteins. Proc. Natl. Acad. Sci. USA, 81, 1664-1668.

Furukawa, K., Hirose, J., Kimura,T., Yoshino, S., and Hayashida, S., 1993. Gene structural diversity as an index of natural gene transfer. In Guerero and Pedro (eds.), Trends in Microbial ecology. Spain: Spanish Soc. Microbiol.

Furukawa, K., Nakamura, N., and Hirose, J., 1996. Evolutionary relationships of catabolic functions in soil bacteria. In 
Colwell et al. (eds): Microbial diversity in time and space. New York: Plenum Press.

Gunsalus, I.C. and Sligar, S.G., 1978. Oxygen reduction by the $\mathrm{P} 450$ monooxygenase systems. $A d v$. Enzymol., 47, 1-44.

Katagiri, M., Ganguli, B.N., and Gunsalus, I.C., 1968. A soluble cytochrome P450 functional in methylene hydroxylation. J. Biol. Chem. 243 (12), 3542-3545

Koga, H., Aramaki,H., Yamaguchi, E., Takeuchi, K., Horiuchi, T., and Gunsalus, I.C., 1986. CamR, a negative regulator locus of the cytochrome P450cam hydroxylase operon. J.
Bacteriol. 166, 1089-1095.

Ngadiman, H., Suenaga, M., Goto, and Furukawa, K., 2004. Characterization of camphor catabolic genes in $P$. putida GF2001. Proceeding of annual meeting of Japanese Society for Biotechnology. March 23-25, 2004, Hiroshima, Japan.

Waasberger, L.G., Balkwill, D.L., Crocker, F.H., Bjornstad, and Miller, R.V., 2000. Genetic diversity among Arthrobacter species collected across a heterogenous series of terrestrial deepsurface sediments as determined on the basis of 16SrDNA and recA gene sequences. Appl. Environ. Microbiol. 66, 3454-3463. 